\title{
Assessment as a Possibility for Individual Learning and Success in Contextual Pedagogical Learning Environment
}

\author{
${ }^{1}$ Maarika Piispanen, ${ }^{2}$ Merja Meriläinen \\ ${ }^{1}$ University of Jyvaskyla \\ ${ }^{2}$ Kokkola University Consortium Chydenius \\ Finland
}

\begin{abstract}
One of the most significant current discussions in the field of education is the rapidly changing world around us. So far, however, there has been little discussion about teacher education and its role in this changing process. We are slowly moving from constructivist learning theory towards to sociocultural theory of learning where learning is according to Kumpulainen, Krokfors, Lipponen, Tissari, Hilppiö and Rajala [1] viewed as a holistic and dynamic process, in which the individual grows into the culture of the community, its values, practices, and artifacts. The research project, introduced in this paper, focuses on transformational pedagogic and the questions of assessment in the learning process. The aim of the research is to identify modern ways to develop teaching and learning to create individual learning paths and give equal learning possibilities to each child in 21 st century learning environments in the point of wives of curriculum based assessment and holistic planning processes of individual learning paths. The classroom intervention is based on the Contextual Pedagogical approach to Learning (CPAL) as a framework of teacher's 21st Century Civil Skills Pedagogical Content Knowledge [2], [3]. This Design research shows that working in CPAL framework supports learning, where everyone will succeed, through individual learning paths in primary school contexts.
\end{abstract}

\section{Introduction}

It is not only spaces, places and tools you have to take into account in the changing educational process. Understanding the 21 st century pedagogy, knowledge and skills connected to learning processes are in a central part of teachers' professional development [3].

According to Meriläinen and Piispanen [3] the 21st Century Civil Skills Pedagogical Content Knowledge framework will help teachers to create learning environments where the 21 st century civil skills will meet modern pedagogy and core curriculum standards. With the help of this framework, together with the model of Contextual pedagogical approach towards learning, one is able to build a strong pedagogical foundation for a transformational 21 st century learning environment.

"I wouldn't do anything differently. It turned out great!"

"I'm satisfied. Our presentation is clear and it also has pictures."

"I learned a lot about Africa. I learned a lot of other things, as well. I also learned a lot from others' studies."

"Indeed I am satisfied. It was fun to do this!"

These were the thoughts of 6th graders when asked to evaluate the two-week study period they had just finished. In the project Expedition to Africa, the pupils' task was to be explorers, to create an authentic travel diary (a blog, a power point presentation, a web site etc.) of the experiences they had in their imaginary adventures in Africa in different situations, for example the Dakar rally. It was relevant that the reader of the travel diary could identify with the nature (climate, vegetation, animals) and culture of Africa and the different phases of the journey by reading the diary, and looking at the pictures and watching the self-made video attached to it.

This contextual-pedagogical, phenomenon-based and transdisciplinary learning project included many phases that came together to form an entity, namely the trip presentation. Inside the project, each member of a team had room and possibilities to affect their work, the activity of the team and the end result by choosing different stages and tools. In the beginning of the project the pupils were given the criteria of assessment, that is, an accurate description of what is expected of them in order to get a certain grade. Through the criteria, a team was able to set goals for their work and to revise them on the way. Expedition to Africa also worked as an exploration of one's learning: What can my team and I achieve when we put our strengths together?

Bookhart says "Assessment, broadly defined, means collecting information about something to be used for some purpose" [4]. Also the pupil can be seen as the collector of information, who collects information related to his learning as a reflecting actor, sets himself goals, and assesses himself with the information. The task of a teacher, other pupils and possible professionals is to help the pupil make 
use of the information he has collected [4]. At its best, the pupil's environment works as an interactional mirror in the learning process.

"It's unnecessary to chain children's creativity; we should rather let them do things in their own way. A teacher's task is to control their work and give them surroundings where they can fulfill their ideas. A teacher's task is also to challenge the pupils to state reasons for their decisions. This way the pupils really have to ponder their decisions and whether they are appropriate (A class teacher student about the project).

When the entire process of learning is valued, not only the end result but the whole learning process must be assessed. The learning process must be planned so that a pupil can be aware of the criteria of assessment during the process and set goals to his work according to those criteria [5]. For the pupil, the purpose of assessment becomes a guide of learning that helps him become aware of things related to his learning. When assessing, a teacher makes value-based choices that have long-term effects: Is the teacher helping the pupil to see assessment as a possibility to set his work goals, or is assessment a detached issue for the pupil? When assessing a pupil, a teacher should always also assess himself and the further actions related to that pupil: How do we use the information that we have gained in order to pursue something as precious as a pupil's better learning? It is primary for a teacher to understand the meaning of the information gained through evaluation, how it fits into the information that has been gained in other ways, and how to use all this information to achieve a positive change [4].

In this study we want to concretize how to view assessment as a possibility that a pupil can have influence on, instead of seeing it as the final judgment of a project. We also want to see assessment as being constantly beneficial to a pupil, helping him make use of his skills and knowledge in his lifelong journey of learning. This kind of activity takes assessment a step closer to evaluation: Evaluation means using assessment information to make judgments about the worth of something [4].

When moving teaching and learning from traditional pedagogy to transformational pedagogy, you have to imagine totally new ways to think about teaching and learning [2]. Chaltain [6] points out some examples of transformational thinking: According to the traditional conception a pupil is primarily responsible for his learning, whereas in transformational pedagogy the teacher and the learning group are seen as sharing this responsibility. The traditional conception also highlights good grades from exams as achievements of a pupil, whereas transformational pedagogy focuses on assessing the process and development of a pupil group's learning project. The goal of transformational pedagogy is no less than to make each pupil so enthusiastic about learning that it can become a passion. [2]

In this research project, 21 st century civil skills are very central: Pupils are encouraged and trained in collaboration, knowledge building, the use of information technology, problem solving, selfregulation, and skillful communication. Also the assessment criteria should encourage using 21st century civil skills. This way the focus of assessment is not the amount of knowledge but the mastery of skills and the application of knowledge. Transformational pedagogy also sees it central to constantly take into account children's individual learning methods, and to make concrete connections between the issues studied and the children's experiences of the world. This means that the same factors that guide children's action in their spare time can be viewed as possibilities for school to help pupils learn better in the framework of the $21 \mathrm{st}$ century: The key factors in learning are to identify and acknowledge individual mastery, strengths and creativity. At their best, these factors can be a starting point for getting enthusiastic about learning - and teaching. The concepts that are related to the transformational school also describe the contextualpedagogical approach [7].

During this research project we have noticed that the way a teacher succeeds in planning his teaching is in key position in transformational pedagogy. The Finnish core curriculum expresses the aim of assessment clearly [8] but often lacks tools that enable a teacher to create a learning process where assessment functions as a positive possibility from the pupil's point of view.

"Assessment during the course of studies must be truthful and based on a diversity of evidence. The assessment is to address the pupil's learning and progress in the different areas of learning. The assessment takes into account its own role in the learning process. Pupil assessment forms a whole, in which ongoing feedback from the teacher plays an important part. With the help of assessment, the teacher guides the pupils in becoming aware of their thinking and action and helps them understand what they are learning. The pupil's progress, work skills, and behavior are assessed in relation to the curriculum's objectives and descriptions of good performance." [8]

Teachers often have will to renew their teaching, but the busy daily life and lack of knowledge of how to renew traditional teaching prevent teachers from making comprehensive pedagogical transformation. The ongoing pressure towards school transformation often causes teachers to renew their teaching with only small practical changes, "tips", instead of transforming the whole pedagogy. Thus, teachers get tired of the ongoing small changes and pressures. As a solution for this, during the last couple of years, we have developed a contextual-pedagogical model that 
works as a teacher's tool for planning transformational, contextual-pedagogical learning. In this research article we will open the contextualpedagogical model and its use a tool for planning phase by phase. The stages of planning as we see them are the following represented in Figure 1.

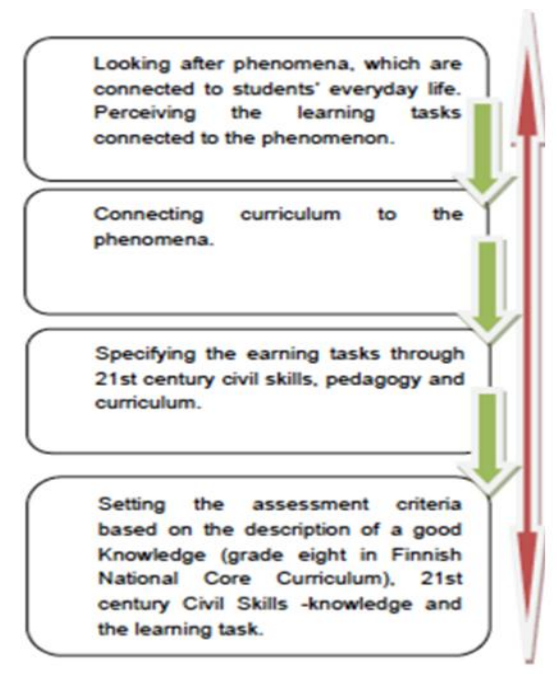

Figure 1. The interacting stages of planning

The contextual-pedagogical model highlights the exploitation of the pupil's experiences of the world in order to achieve the learning objectives of the curriculum. On this journey, the assessment criteria work as the pupil's map,

\section{The research framework}

In this study intervention, the participants were 20 pupils on sixth grade, and pre-service teachers who worked as the pupils' teachers, planning and fulfilling a two-week-long contextual-pedagogical learning whole. Contextual-pedagogical model was new to both the pupils and the teacher students, which gave the researchers an excellent starting point to explore the adaptation of the model as a tool for teachers and also see the function of the model through the learning experiences of pupils. After the learning whole both students and pupils were asked about their evaluations of the learning whole.

In this study, we, as researchers, were aware and took into account the pupils' age and developmental phase. 12-year-olds are in a very varying stage in their development: According to the psychodynamic theory, 7 to 12-year-old children are in a latency phase, but on the other hand, 11 to 12 -year-olds can be viewed as preadolescents who move from the concrete operational stage to the formal operational stage. [9] As a target group, 11 to 12-year-olds are a very heterogeneous group as far as their development is concerned. However, we saw this as a positive thing since it gives us versatile information on how the pupils achieve the objectives of this learning project: Pupils work in a familiar group and classroom environment on a new kind of learning project. They are very action-oriented and can express themselves clearly. On the basis of their development stage, we assumed the pupils to participate in the project rather enthusiastically and to be able to answer the research questions asked of them afterwards.

The research strategy can be characterized as descriptive, hermeneutical-phenomenological action research, where the researchers guide the class teacher students' planning and follow the fulfillment of the model in action. According to the phenomenological meaning theory, the sense of community and building meanings through interaction with his environment are central for a human being. Meanings are built according to each person's experiences of the world, which we aim to interpret, explain and understand in the hermeneutical framework [10].

In this study, we tried to reach the experiences of the pre-service teachers and pupils participating in the study on the contextual-pedagogical learning project from different angles: planning fulfillment, and foremost assessment, where central things are both the students' experiences on creating a learning project, and pupils' experiences of the project. It was central to aim to understand the relevant factors of a study project that is based on versatile starting points of assessment, as regards the planning work and progress of a teacher. Also it was central to highlight pupils' experiences on studying based on $21^{\text {st }}$ century skills, where they were allowed to set their own learning objectives on the basis of the assessment criteria given to them.

A central method in the study is content analysis that is based on the logic of theory-based reasoning. The research topic is approached by means of abduction, this meaning dialogue between material and theory, where approaches vary between inductive (material-based) and deductive (theorybased) inference [11]. Thus, the hermeneutical circle runs between our material (the written experiences of class teacher students and pupils) and theory (the contextual-pedagogical model), and the interpretation of the researchers that is in between.

The presence of two researchers and the versatile content analysis add reliability to the study, since the researchers are able to get back to the material several times during the different stages of the research. Central for the interpretations is also that the researchers have been present in the intervention as guiding teachers. 
The following questions are chosen as central research tasks:

- What turned out to be the most central developments when pre-service teachers assessed their progress in planning a learning project from contextual-pedagogical and phenomenon based learning points of view?

- How did pupils experience the contextualpedagogical, transformational learning project when compared to traditional way of studying?

- How were individual ways of learning represented in the pupils' answers?

\section{Well planned is half done}

According to Meriläinen and Piispanen [3] the teacher's challenge in today's education is to strengthen the students' natural ways to learn and produce information in new learning environments. Learning is thus seen as something happening in connection with an individual and his or her environment. In the beginning of the planning process it is important to reflect on the important and interesting things in pupils' lives. Current TV shows (Junior Master Chef, Amazing race, Survivors, etc.) or interests that are typical at a certain age (circus, hobbies, mopeds, etc.) are often among these things.

\section{Table 1. Tools for planning at the first stage}

\begin{tabular}{|l|l|l|l|}
\hline Hot Spot & $\begin{array}{l}\text { Phenome } \\
\text { non }\end{array}$ & Pupil's role & Instruction \\
\hline $\begin{array}{l}\text { Project } \\
\text { globe } \\
\text { trotters }\end{array}$ & $\begin{array}{l}\text { Expeditio } \\
\text { n to }\end{array}$ & $\begin{array}{l}\text { Travel } \\
\text { blogger } \\
\text { Manuscricater }\end{array}$ & $\begin{array}{l}\text { Congratulation } \\
\text { s! Your group } \\
\text { has won a trip } \\
\text { to a folk music } \\
\text { festival in } \\
\text { Africa Your } \\
\text { journey starts } \\
\text { from Kokkola } \\
\text { and your } \\
\text { destination is } \\
\text { Zambia folk } \\
\text { music festival. }\end{array}$ \\
& & $\begin{array}{l}\text { Write a blog of } \\
\text { your trip; add } \\
\text { also videos of } \\
\text { the different } \\
\text { phases of your } \\
\text { journey. }\end{array}$ \\
\hline
\end{tabular}

Making links between a child's life and the learning topic gives the topic a meaning and concretizes it. It is important for a teacher to do this reflection of a pupil's life before taking a look at the curriculum so that the pupil's experiences of the world would guide the teacher's thinking process. After finding the "hot spot", the teacher must decide what is the topic of the learning project, what is the central area studied, and what is the pupil's active role in this project. The following table (see Table 1) is taken from the first stage of planning the Expedition to Africa project, created by pre-service teachers.

After the idea generation phase the teacher's task is, through curriculum, to consider the performance and learning objectives that the pupil is expected to achieve during the project. This also includes contemplating the contents of different learning wholes and joining them to form a whole that serves the topic (stage 2). It is of primary importance to understand the links between curriculum and the project, as only that way the teacher can see the meaningfulness of the project and set the pupils the assessment criteria. These criteria are in direct connection to the learning objectives that are then defined for the project. In a way, the curriculum is in this phase read conversely: From learning objectives towards contents, so that it the goals of the projects can be defined.

After the teacher has defined and written down in his plan the links between curriculum and the project he will be able to compile the pupils a more detailed instruction (phase 3), which help the pupil to get a grip of the future project and its stages as presented in Figure 1. Through these stages, the pupils can make plans in their team about how to advance in the project: how to proceed, what tools and equipment are needed, and how the tasks are divided in the team? In this study the planning process of the teacher students was guided so that the learning project would enable different ways to work and learn, in different learning contexts, with different equipment.

\section{Example of detailed instruction:}

a) Your team takes a part in a prize trip of The Globetrotters. Each group can choose their destination from the given options, for example the Dakar rally. Your trip starts from Helsinki and ends to the Dakar rally stretch. Your task is to write travel diary of your journey (a blog, a PowerPoint, a webpage etc.). Remember the important and reckless details!

b) On the way the explorers experience extreme climatic conditions in the most central nature areas of the continent, and experience the continent through these conditions, by living them through and doing things. The blog should tell about the following things:

- Where is the site situated? (on a map, what country does it belong to?)

- What are the nearest cities of the site? (population, population density) 
- What is the climate like on the site? (climatic zone)

- What kind of vegetation does it have? (vegetation zone)

- What kind of special cultural features can you spot on the site? (people, tribe, clothes, food, music, language, science, arts, trades, living and family life, religion)

- What sights and activities can you find on the site?

- What animals can you see there?

c) The blog should convey an experience of the trip to those who are not brave enough to make a journey like that! How should you prepare and equip yourself? How long does the journey take? How to get to the site and how much does it cost?

d) The blog must include pictures and a video clip of the trip! The video clip is an excerpt of real life, starred by the people that participated in the journey!

"The instruction was open on purpose, because we thought that a pupil can himself choose the ways to plan and carry out the task. We had given examples of different pieces of equipment that can be used in the task. This worked as an excellent means of individualization. Each pair of pupils chose the best and most suitable pieces of equipment for themselves. Now we did not need to "force" anyone to use for example Movie Maker, but they had Power Point as an option that works as any other electronic tool. The idea was that pupils could decide on nearly everything, as long as the given criteria were fulfilled. Some pupils tried a method first, but changed to another method, because it did not feel like their way of working." (Pre-service teacher).

In connection with the instruction the teacher also compiles the criteria for assessment as presented in Table 2. They are based on the curriculum's description of good performance, the requirements given in the instruction, and the $21^{\text {st }}$ century skills. With the help of the criteria both teacher and pupils can clearly see what kinds of things are assessed in the project and what kind of work is needed in order to achieve the different objectives. The assessment criteria given in the beginning of the learning project help a pupil set him goals and revise his direction on the course of the project. Piispanen [12] states that a pupil must be able to feel command of his assessment, as he is aware of the assessment targets and the effects of his action to the assessment. This, in its part, develops thinking and planning skills, which are seen as central areas in the $21^{\text {st }}$ century pedagogics.
Table 2. An example of assessment criteria based on the Finnish National Core Curriculum

\author{
Planning \\ Excellent \\ -task is appropriately planned \\ -task shows creativity -planning shows cooperation \\ Good \\ -plan must be revised \\ -ideas are borrowed from others \\ Satisfactory \\ -planning must be guided to some extent
}

Responsibility

\section{Excellent}

-responsibilities are evenly divided among pupils

-everyone knows his own tasks

-everyone does his share

-group works towards a shared output

Good

-responsibilities are not clearly divided, but work proceeds

-tasks are partly overlapping, some tasks are forgotten

-work is not equal

\section{Satisfactory}

-work is not equal

-responsibilities are not divided nor is work organized spontaneously

-some tasks remain undone

\section{Cooperation}

Excellent

-cooperation is great

-pupils help each other when needed

-pupils have check points

-constructive feedback to one another

-peaceful working environment

-others' ideas are respected

Good

-cooperation is good but there is no discussion about the progress of the work

-peaceful working environment

\section{Satisfactory}

-cooperation is not without problems

-pupils must be reminded of a peaceful working environment -pupils work separately and do not discuss the work

-pupils get sidetracked every now and then

-no feedback to other pupils

\section{Output}

\section{Excellent}

-output is appropriate

-work is original and creative

-all things given in the instruction are paid attention to

-knowledge of map and scale is shown excellently

-work shows understanding of nature and cultural features and

their effects on local people's lives and living conditions

-self-made statistics are used in the work

-expression is versatile, skillful and creative and uses topic-

related concepts easily

-work is visually representative

Good

-output is good and appropriate 


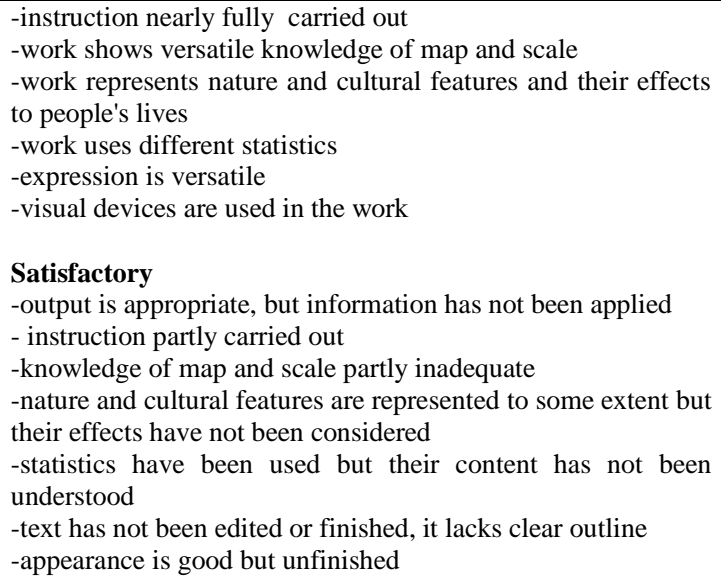

The purpose of the assessment criteria is to make the pupil see the learning process as meaningful and possible for him as regards his strengths. The starting point of this is openness: every pupil knows throughout the whole learning project what is expected of him and how he can respond to these expectations. Each pupil has the possibility to bring his strengths to the team, and assessment focuses on performance and achievement in the project. Creativity, pupils' own performance and individuality are given space:

"Telling the pupils about the assessment criteria is a thing that I have realized by this autumn. It is a lot easier for the pupils to work and set themselves goals when they know what are assessed and what is required for each grade." (Pre-service teacher)

\section{Results}

With this study, we wanted to find out if a contextual-pedagogical project can achieve what we saw as the central objective of the model: enabling individual learning paths and learning through one's own strengths in the framework of $21^{\text {st }}$ century skills. In addition, we wanted to examine from the point of view of assessment, whether pupils also see a learning project as an individual possibility [3]. Since the contextual-pedagogical model represents the model of transformational school, we wanted to define the central developments and challenges in adopting the model from a teacher's perspective.

\subsection{A look at Pupils' Experiences}

To meet these challenges, ideal-learning environments should be developed. In the $21^{\text {st }}$ Century CSPCK - model [3], [13], [14] the emphasis is put on competency, performance and capabilities. The key question in learning situations is how the information is received and will be used rather than what the information is. In the learning environments that emphasise mainly information, it is easy to forget diverse learners i.e. different learning styles, personal learning capacities and multiple intelligences etc. In a contextual-pedagogical approach towards learning, a special attention is paid to learning in authentic learning environments with authentic learning tasks and to the authentic strategies to accomplish these tasks.

In our study, topic that came from the pupils' experiences of the world, an adventure journey, excited the pupils very much: Except for one pupil, all (19) pupils were of the opinion that the project appeared interesting at the latest when they started to work on it. A well-planned start and motivating turned out to play an important role again [15].

In the beginning of the learning project the students introduced the project to the pupils and gave those written instructions and assessment criteria. These were then reviewed together. 90 per cent of the pupils reported they understood from the papers what is assessed and what is expected of their work. Two pupils felt that these things were not clear to them at first. The pupils' grasp of the expectations was a surprising study result, since receiving the assessment criteria in the beginning of a learning project was a totally new thing for them. This result affirmed the fact that it is important to tell a pupil, taking into account his developmental stage, what is expected of him so that he can set himself individual goals and strive towards them [16].

This project that was carried out in dense social interaction requires the participants a lot of social interaction, creativity, searching and application of information, and problem solving. In other words the learning project trained several kinds of skills where peer support played a central role in learning. In the framework of his developmental stage, a pupil can simultaneously be very sociable and socially incompetent [17]. Therefore, the aim of the interactional situations in the learning project was to reinforce the different sides of relationships, which are so important to this age group, through the progress of 21st century civil skills: comradeship, stimuli, physicality, conception of oneself, social comparison and emotive meanings.

A central result that supports the idea of an individual learning path was that pupils experienced different things as the best parts of the project. This result shows that the pupils have divided responsibility areas and taken their own strengths into consideration, as well as gathered their responsibility areas together into an entity as the outputs were presented in a shared platform. This kind of a process shows a versatile progress of $21 \mathrm{st}$ century civil skills. In our study we could also see that a contextual-pedagogical approach enables demonstration of individual competency, as all (19) but one pupil were of the opinion that the project demonstrated their competency well enough without a traditional test. According to Marandos [18], the 
tasks and objectives must be in right relation to the pupil's possibilities, competencies and abilities. Then it is possible to actually assess what the pupil is striving for, and what he can achieve. It is also important to notice that the character of assessment drastically changes when it is made visible to the pupil in the beginning of a project. In practice, this means a teacher must beforehand contemplate the objectives of the learning period, the tasks that help advance towards the objectives, what kind of information one wants to get with assessment, and what best shows competency [4].

According to the responses of the pupils nobody was unsatisfied with their output or saw any major shortages in it. As this response is mirrored to the pupils' age and 6th-graders satisfaction towards their work in general, the result can be seen as rather positive. We feel that one reason for this positive result is that the pupils were able to use their own strengths when working together, and the work included many kinds of phases and actions, so that everyone was able to exploit their expertise and competency. In addition to taking into account one's strengths, the pupils had to bear in mind the shared output that they were heading towards even when they divided work responsibilities among themselves. For example the authentic situation, the play, that was to be attached to the output, included several stages from manuscript to acting, filming and embedding. The work joined together individual skills and tasks as well as collaborative filming of the play. Despite its challenging nature, the filming of the scene was considered pleasant by 85 per cent of the pupils. It is also worth mentioning that all except one pupil were of the opinion that it was fun to watch other pupils' presentations and you learned new things about the topic from them.

It was interesting in the pupils' responses that nearly every pupil stated that they were satisfied with the amount of knowledge. However, they also experienced that searching for information was the most challenging part of the project. It remains a topic of consideration whether they were happy with the amount of knowledge because searching and choosing it had been so challenging, or because the school emphasizes the amount of knowledge so much that the pupils felt it was important to present a lot of information? In any case the pupils' response shows that they were satisfied after having handled such a challenging task.

As this type of a project was rather new to the pupils, adopting it and working on it required a lot of energy. Afterwards, several pupils were obviously satisfied with their work, but also exhausted about the intensity of the project. Despite this, the pupils would have been ready for a new project right away. The majority of the pupils, (13/20) told in their responses, that they would do nothing differently, if they were to start the same project again. This tells that they were satisfied with their outputs.

The things that the pupils experienced as challenging required real problem-solving: searching for information, finding relevant things, using foreign sources, and using negotiation skills in disagreements in social situations were all needed in authentic situations and taught the pupils to cope with them. What made the situations especially interesting was that the pupils did not need solutions for these situations from the teacher, but were able to handle them themselves. This reflects needs-based setting: the pupils felt it important to solve the situation and were able to find the means to solve the problems.

The pupils worked in pairs all over the school nearly all the time. There have been no problems whatsoever with peace during this time. On the contrary, the pupils received praise for their concentration and goal-orientedness:

"It was delightful to see how the pupils supported each other's. A small part of the pupils are totally unfamiliar with electronic material. Then those pupils who knew were happy to guide the others. My role was mainly to supervise and circle around looking how the work proceeds, and if needed, guide them to the right way if they had stepped astray. Sometimes I felt myself totally useless." (Pre-service teacher).

\subsection{A review of the teacher's development areas}

The Figure of 21st Century Civil Skills Pedagogical Content Knowledge (21st Century CSPCK) (see Figure 2) attempts to identify the nature of vast pedagogical knowledge required when turning learning from traditional to transformational i.e. blending the 21 st century civil skills into the authentic earning contexts and the curriculum.

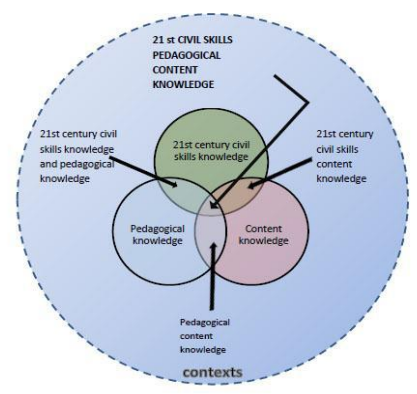

Figure 2. The 21st Century Civil Skills Pedagogical Content Knowledge (21st Century CSPCK). (Following Mishra \& Koehler 2006, 2009) 
The basis of the framework is the understanding that teaching itself is a highly complex activity that draws on many kinds of knowledge. This knowledge, as Ashe and Bibi [19] highlight, is diverse and includes both content and pedagogical knowledge. In recent years a new type of knowledge has been raised to attention that of 21 st century skills or $21 \mathrm{st}$ century civil skills as Finnish National Board of Education has named the knowledge in the curriculum renewing process. The 21 st Century CSPCK -figure articulates the role of 21st century civil skills in the process of teaching and learning in a really blended manner. In 21st Century CSPCK model the emphasis is put on competency, performance and capabilities and the key question in learning situations is rather how the information will be used than what the information is. Meriläinen \& Piispanen [20].

The dimensions of competency in $21^{\text {st }}$ century teacher hood concretize in our study, where class teacher students were to plan and implement a contextual-pedagogical learning whole and after that assess the whole project from the point of view of their own learning. The central development areas of the students in the planning of the contextualpedagogical learning whole could after phenomenological research analysis be divided into three main categories:

- Understanding the significance of curriculum and planning

- Understanding what are contextual-pedagogical approach and phenomenon-basedness

- Creating the kind of learning projects that support individual learning possibilities and train $21^{\text {st }}$ century civil skills

The students stated that knowing the curriculum well is the basis, so that the teacher can see connections between things that exist in the child's experience of the world and the curriculum [16].

"Getting to know the curriculum has been a great journey. It started subject-wise and continued with a deeper multidisciplinary familiarization. This broadened my thinking! I can see in a small moment objectives from several subjects that are written in the curriculum. Opening the curriculum has given me means to guide different kinds of learners. Knowing the curriculum enables thinking and through that freedom of planning teaching in a way where only your creativity and imagination are the limits" (Pre-service teacher).

The responses of the students showed that their knowledge of the curriculum deepened from subjectbased scrutiny to multidisciplinary one, and finally to a deeper understanding of the curriculum so that they learned to raise learning contexts and phenomena examined from a child's experience of the world and the surrounding society [3]. At this stage the starting point of a teacher's planning work can be seen as being primarily the phenomena of the surrounding society, which the teacher mirrors to the curriculum. Thus, the starting point is not, even from curricular perspective, to learn any subject content for itself, but to help the pupil understand that the contents actually gain meaning when they are linked to a context. This, naturally, brings motivation and joy to learning [18] [15]. Meriläinen and Piispanen [2] [3] state that the curriculum creates content and assessment objectives to the scrutiny of a societal phenomenon.

Opening the contextual-pedagogical model through concrete action was a central development area, which could be seen from the research responses:

"Contextual-pedagogical learning emphasizes the importance of authentic learning and authentic learning environments are connected to it. Creativity plays a central part. In contextual-pedagogical approach the most important task of the teacher is to create conditions and surroundings for learning, and to enable learning processes where the pupils have a chance to decide on the objectives of their learning in the direction of shared objectives (the curriculum)" (Pre-service teacher).

A teacher has a central role of being the builder of future learning. He will help pupils to learn in ways and with tools that are natural to them in new kinds of learning environments that link school and society. Pupils should be encouraged to search, handle, apply, evaluate and produce information in a variety of ways. [2]

The learning project that was aimed for pupils and planned by students started from questions of enabling assessment and taking into account individual ways of learning. In contextualpedagogical approach these are the central issues that the whole approach is built on and that should be seen as the basis of the learning process already in the planning stage, during the project, and in the end, when finishing the project. Taking into consideration individual learning styles was raised as one of the central development areas in students' responses.

'Even though the instruction was same for all pupils, every pupil had a chance to work according to his resources. The things that were required could be found in almost every output, and this way the pupils could show their competency to the teacher. The outputs turned out different from each other, each pupil concentrated on working according to his skills and the most important thing was that every pupil was able to work, had the energy to work, and 
succeeded to make an output. Each their own kind." (Pre-service teacher)

\section{Conclusion}

At the heart of the 21st Century Civil Skills Pedagogical Content Knowledge framework is the complex interplay of three primary forms of knowledge: 21st Century Civil Skills Knowledge (21st Century CSK), Pedagogical Knowledge (PK), and Curriculum Content Knowledge (CCK). It is essential to find the 21st Century Civil Skills Pedagogical Content Knowledge point of intersect, where the three primary forms of knowledge meet each other and use that essence as a starting point when creating innovative and enthusiastic learning situations. As Meriläinen and Piispanen [2] highlight, the planning process is to be viewed from at least three different angles as pictured in Figure 2. What do we mean by that is that the emphasis of learning should not lie on curriculum contents (subject contents) themselves, but these contents should act as tools for accomplishing 21 st century civil skills by arranging learning situations and environments as authentic as possible to support vast and deep understanding of every day phenomena. The $21 \mathrm{st}$ century civil skills should also not be seen as isolated skills or learning targets, but they should be examined as visible parts of a learning context. Together all the three knowledge areas will create a successful and pedagogically meaningful learning process produced by students and supported by teachers.

As shown above, one of the most significant differences between traditional and transformational learning process lies on assessment and the role of assessment in learning process. In contextual pedagogical learning assessing will act as a tool for guiding students through the learning path -the learning aims will come true through the learning tasks based on assessing criteria. This is, as Meriläinen and Piispanen [2] states, particularly important in order that students will understand and recognize what are the learning expectations and how the assessment will come true. As to say, the aim of the assessment is to support learning also after the learning process. Each learning process is a journey of exploration to learning, recognizing skills and to utilize these skills.

\section{References}

[1] Kumpulainen, K., Krokfors,L., Lipponen,L., Tissari, V., Hilppö, J. and Rajala, A. (2009). Learning Bridges Toward Participatory Learning Environments. University of Helsinki.

[2] Meriläinen, M. \& Piispanen, M. 2012. Learning as a Phenomenon - Manuscript of Phenomenon Based Learning. Toim: L. Gómez Chova, A. López Martínez, I.
Candel Torres. Edulearn12 : 4th International Conference on Education and New Learning Technologies IATED. $5447-5454$.

[3] Meriläinen, M. \& Piispanen, M. 2013b. Journey of exploration on the way towards authentic learning environments. Teoksessa: D. G. Sampson, J. M. Spector, D. Ifenthaler \& P. Isaias (toim.) Cognition and exploratory learning in the digital age. IADIS. 159-169.

[4] Bookhart, S. 2004. Assessment theory for college classrooms. http://www.gwu .edu/ fellows/ GTAP/Online $\% 20$ Makeup /T-L\%20Presentation\%20Readings/ Assessment\%20Theory_2004-Winter_p5.pdf

[5]Atjonen, P. 2013. Perusopetuksen opettajat oppilasarvioinnin tekijöinä. Teoksessa: P. Atjonen (toim.) Työ Arvonsa ansaitsee. Juhlakirja 113 -vuotisen kajaanilaisen opettajankoulutuksen kunniaksi. Oulun yliopisto, kasvatustieteiden tiedekunnan julkaisuja. 104118.

[6] Chaltain, S. 2011. http://www.samchaltain.com/blog3. 5.2012.

[7] QED Foundation. 2012. Q.E.D. Choises for learning. Choises for live. http://qedfoundation.org/

[8] Finnish National Core Curriculum. 2014. Juvenes Print - Suomen Yliopistopaino Oy, Tampere 2015.

[9] Piaget, J. \& Inhelder, B. 1977. Lapsen psykologia. Jyväskylä: Gummerus.

[10] Laine, T. 2007. Miten kokemusta voidaan tutkia? Fenomenologinen näkökulma. Teoksessa: J. Aaltola \& R. Valli (toim.) Ikkunoita tutkimusmetodeihin II. Näkökulmia aloittelevalle tutkijalle tutkimuksen teoreettisiin lähtö koht iin ja analyysimenetelmiin. Jyväskylä: PS-kustannus. 2845.

[11] Tuomi, J. \& Sarajärvi, A. 2004. Laadullinen tutkimus ja sisällönanalyysi. Jyväskylä: Gummerus Kirjapaino Oy.

[12] Piispanen, M. 2013. Anna mun oppia ja osata! Oppimisen konteksti ja pedagogiikka uudistavan koulun avaimina. Teoksessa: P. Atjonen (toim.) Työ arvonsa ansaitsee. Oulun yliopisto, Kasvatustieteiden tiedekunnan julkaisuja. 139-154.

[13] Herrington, J. (2006). Authentic e-learning in higher education: Design principles for authentic learning environments and tasks. In T.C. Reeves \& S. Yamashita (Eds.), Proceedings of World Conference on E-Learning in Corporate, Government, Healthcare, and Higher Education 2006 (pp. 3164-3173). Chesapeake, VA: AACE.

[14] Herrington, J. (2012). Design-based research: Implementation issues in emerging scholar research. In T. Amiel \& B. Wilson (Eds.), Proceedings of World Conference on Educational Media and Technology 2012 (pp. 1-6). Association for the Advancement of Computing in Education (AACE). 
[15] Sahlberg, P. 2013 a. Uteliaisuudesta intohimoon. http://pasisahlberg.com/uteliaisuudesta-intohimoon/

(11.11.2013)

[16] Brophy.J. 2010. Motivating Students to Learn. Lawrence Erlbaum Associates, 2004.

[17] Keltinkangas-Järvinen, L. 2010. Sosiaalisuus ja sosiaaliset taidot. Helsinki:WSOY

[18] Marandos, S. A. and Randall, I. 2012. Engaging and Motivating Students. Five research based models for engaging students to be productive. http://asbbs.org/files/ASBBS2012V1/PDF/M/MarandosS2. pdf.

[19] Ashe, D., Bibi, S. (2011). Unpacking TPACK and students' approaches to learning: Applying knowledge in pieces to Higher Education teaching and learning. Ascilite 2011: Changing Demands, Changing Directions, Hobart, Australia: University of Tasmania.

[20] Meriläinen, M. \& Piispanen, M. 2015. Live, Laugh and Love to Learn. Turning Learning from Traditional to Transformational. In Pedro Isaias, J. Michael Spector, Dirk Ifenthaler \& Demetrios G. Sampson (Eds.). E-Learning Systems, Environments and Approaches : Theory and Implementation. 69-81. 